\title{
HIGH LEVEL WASTE FACILITIES - CONTINUING OPERATION OR ORDERLY SHUTDOWN
}

\author{
PECEVED \\ $M A O>1998$ \\ OSTI
}

Loral A. Decker

\section{MNSTE}

DISTRIBUTION OF THIS DOCUMENT IS UNLMTEO

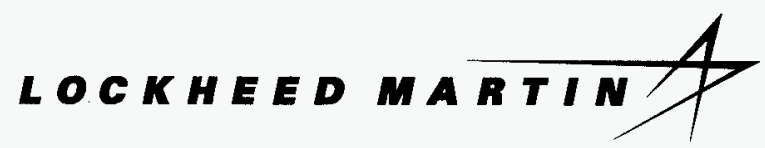




\section{DISCLAIMER}

This report was prepared as an account of work sponsored by an agency of the United States Government. Neither the United States Government nor any agency thereof, nor any of their employees, makes any warranty, express or implied, or assumes any legal liability or responsibility for the accuracy, completeness, or usefulness of any information, apparatus, product, or process disclosed, or represents that its use would not infringe privately owned rights. Reference herein to any specific commercial product, process, or service by trade name, trademark, manufacturer, or otherwise does not necessarily constitute or imply its endorsement, recommendation, or favoring by the United States Government or any agency thereof. The views and opinions of authors expressed herein do not necessarily state or reflect those of the United States Government or any agency thereof. 


\section{HIGH LEVEL WASTE FACILITIES- CONTINUING OPERATION OR ORDERLY SHUTDOWN \\ EIS NO ACTION ENGINEERING STUDY}

Published April 1998

Idaho National Engineering and Environmental Laboratory Department

High Level Waste Program

Lockheed Martin Idaho Technologies Company

Idaho Falls, Idaho 83415

Prepared for the

U.S. Department of Energy

Under DOE Idaho Operations Office

Contract DE-AC07-94ID13223 


\section{ABSTRACT}

Two options for Environmental Impact Statement No-action alternatives describe operation of the radioactive liquid waste facilities at the Idaho Chemical Processing Plant at the Idaho National Engineering and Environmental Laboratory. The first alternative describes continued operation of all facilities as planned and budgeted through 2020. Institutional control for 100 years would follow shutdown of operational facilities. Alternatively, the facilities would be shut down in an orderly fashion without completing planned activities. The facilities and associated operations are described. Remaining sodium bearing liquid waste will be converted to solid calcine in the New Waste Calcining Facility (NWCF) or will be left in the waste tanks. The calcine solids will be stored in the existing Calcine Solids Storage Facilities (CSSF). Regulatory and cost impacts are discussed. 


\section{SUMMARY}

Waste storage and treatment facilities at the Idaho Chemical Processing Plant have been in operation since 1953. Plans for treatment and disposal of radioactive liquid and mixed hazardous waste are underway. The Department of Energy, Idaho Operations Office, is preparing an Environmental Impact Statement to comply with the NEPA process. The EIS will discuss a "No Action" treatment and disposal alternative. Other extensive treatment and disposal alternatives will be discussed in other reports. The continuing operations option of the No-action Alternative will complete planned waste Idaho Chemical Processing Plant operations. The orderly shutdown option will quickly complete in-process batches and shut down early without completing the planned treatment of liquid wastes.

Continued operation of the New Waste Calcination Facility (NWCF) will complete calcination of the radioactive liquid waste until the inventory is depleted and the resulting calcine stored in the existing bin sets for an indefinite period. Settlement Agreement milestones for calcining all sodium bearing waste and emptying the Tank Farm by December, 2012 will be fulfilled. The Settlement Agreement milestone to treat the calcined solid waste to be ready for removal from the state by 2035 will not be met. The total cost for operation of the Calcine Solids Storage Facility bin sets including institutional control for 100 years is estimated to be $\$ 27,371,000$. The total No Action alternative cost for continued operation is estimated to be $\$ 1,170,331,000$ (Through 2020 except for the CSSF).

Orderly shutdown will begin as soon as directed. Batches that are in the process of being treated would be completed and feed tanks will be rinsed. The orderly shutdown cost is estimated at $\$ 36,080,000$. 


\section{CONTENTS}

INTRODUCTION

Purpose of Study

Background

The NEPA Environmental Impact Statement Process 2

Assumptions for Continuing Operation Alternative $\quad 2$

Assumptions for Orderly Shutdown Alternative 3

FACILITIES AND PROCESSES

New Waste Calcining Facility (NWCF-CPP-659)

ICPP HEPA Filter Leaching System (CPP-659)

NWCF Debris Treatment Facility (CPP-659)

ICPP Process Equipment Waste (PEW) System

Liquid Effluent Treatment and Disposal (LET\&D)

ICPP Tank Farm

High-Level Liquid Waste Evaporator (HLLWE)

Calcine Solids Storage Facilities (CSSF)

Gaseous Waste Systems

Support Facilities

DESCRIPTION OF THE NO-ACTION ALTERNATIVES

Continuing Operation

Orderly Shutdown

PROJECTS

Electrical and Utility System Upgrade Project 15

NWCF modifications for the MACT rule. 15

Radioactive Liquid Waste Tanks $\quad 16$

Basis for the MACT Project Data Sheet 16

Basis for the Radioactive Liquid Waste Tanks Data Sheet 23

$\begin{array}{ll}\text { REFERENCES } & 30\end{array}$

\section{TABLES}

Table 1. Inventory of the CSSF bin sets as of February 1998

Table 2. Tank Farm Volumes 10

Table 3 Continuing Operation Cost Estimate 12

Table 4 Project Data Sheet for NWCF MACT Compliance Facility 17

Table 5 Project Data Sheet for Radioactive Liquid Waste Tanks 24 
viii 


\title{
HIGH LEVEL WASTE FACILITIES - CONTINUING OPERATION OR ORDERLY SHUTDOWN
}

\author{
EIS NO ACTION ENGINEERING STUDY
}

\section{INTRODUCTION}

\section{Purpose of Study}

The U. S. Department of Energy Idaho Operations Office (DOE-ID) is preparing an Environmental Impact Statement (EIS) for High-Level Waste and Facilities Disposition. The EIS will be prepared in accordance with the National Environmental Policy Act (NEPA) to support the decision-making process regarding high-level waste (HLW) management at the Idaho National Engineering and Environmental Laboratory (INEEL). The EIS evaluates all reasonable alternative proposals and environmental impacts. The "no-action" alternative is a baseline alternative for comparison of environmental impacts of the other alternatives. This study describes two no-action alternatives.

\section{Background}

In 1953, the Idaho Chemical Processing Plant (ICPP) located at INEEL was chartered to reprocess government-owned spent nuclear fuel (SNF) to recover fissile uranium. With the diminishing need to recover and recycle this material, the United States Department of Energy (DOE) discontinued reprocessing SNF in April 1992. This shifted the ICPP focus toward continued management and disposition of SNF and waste accumulated from previous reprocessing activities.

The current DOE mission for the ICPP includes: (1) managing SNF, and (2) managing and treating for disposal (a) radioactive and hazardous wastes generated during past SNF reprocessing, (b) waste generated from other on-going operations at the INEEL, and (c) waste that will be generated during future waste processing and decontamination and decommissioning activities. Milestones for cleanup activities are established in the October 1995 Settlement Agreement between the State of Idaho, the U.S. Navy, and DOE. The Settlement Agreement court order requires the DOE to empty the tank farm tanks contained in pillar and panel vaults by mid-year 2009 and calcine the liquids stored in the ICPP Tank Farm Facility by year 2012. (DOE 1998) 
HLW is the highly radioactive waste material that results from the reprocessing of spent nuclear fuel. HLW includes liquid waste produced directly from reprocessing and any solid waste derived from the liquid that contains a combination of transuranic contaminants and fission products in concentrations requiring permanent isolation. High-level waste may include other highly radioactive material that the $U$. S. Nuclear Regulatory Commission, consistent with existing law, determines requires permanent isolation. HLW at the INEL includes calcine solids. Radioactive liquid waste includes sodium-bearing waste yet to be calcined. (USDOE 1997a).

The present ICPP HLW waste treatment activities produce a granular solid waste, or calcine, that contains fission products, transuranic isotopes (TRU), and fuel-cladding material. Decontamination and laboratory activities at the ICPP produce liquid radioactive sodium-bearing waste (SBW) that is currently stored in the ICPP tank farm tanks. These and other operations at the ICPP produce liquid wastes that contain low levels of radioactivity and TRU. The radioactive liquid wastes and related calcined solids are considered mixed waste because of hazardous constituents.

The no-action alternatives provide environmental baselines against which the impacts of other alternatives can be compared.

\section{The National Environmental Policy Act (NEPA) Environmental Impact Statement (EIS) Process}

Under NEPA, the EIS process must describe a no-action alternative that describes the consequences of not changing the current operations. The High-Level Waste and Facilities Disposition EIS evaluates new facilities for treating, storage, and disposal of waste and closing facilities to the no-action alternatives of continuing processing and monitoring waste or orderly shutdown.

In the NEPA process, a no action alternative may not necessarily comply with applicable laws and regulations, but it provides an environmental baseline against which the impacts of other alternatives can be compared. (USDOE 1997b)

\section{Assumptions for Continuing Operation Alternative}

- Operation of the NWCF according to the current plan will convert all of the radioactive liquid waste to solid calcine material by 2012 .

- Operation of the NWCF for calcination of SBW and continued SNF operations at ICPP will continue to generate liquid radioactive waste through 2012.

- All radioactive waste systems and infrastructure facilities at ICPP will remain in operation to support the NWCF operation until the NWCF is placed in standby after completion of the tank farm closure.

- Maximum Achievable Control Technology (MACT) licensing requirements will be met by a modification to the off-gas treatment system for NWCF for operation of the NWCF after 2007. (Rawlins1997) 
- Calcination of SBW will be performed at 600 degrees $\mathrm{C}$ to reduce the quantity of added nonradioactive aluminum nitrate. ${ }^{2}$

- The contents of bin set \#1 will not be transferred as part of the no action alternative.(ICPP 1996b) ${ }^{b}$

- A new bin set (\#8) will not be required for the no action alternative because of improved waste management processes. ${ }^{\circ}$

- Low activity liquid waste that is generated after closure of the tank farm will be treated or stored by the waste generators.

- Regulatory requirements will apply to the No Action alternatives for planned activities through planned tank farm closure. (Wichmann 1996; Spaulding et. al. 1998a). Regulatory issues were also discussed by Palmer (1994).

\section{Assumptions for Orderly Shutdown Alternative}

- Decision to shutdown is made in FY-2000.

- None of the waste storage or treatment facilities would be RCRA closed.

- The tank farm will not be RCRA closed.

- Shutdown facilities will be left in safe condition after expenditure of reasonable efforts but will be unmonitored.

- Public access will be restricted until after 2095.

\footnotetext{
${ }^{\text {a }}$ Earlier feasibility studies identified potential high temperature modifications with an estimated TPC of $\$ 6.6 \mathrm{M}$. (Henry Welland, INEL/INT-97-00075, NWCF Process Modification for Sodium-Bearing Waste Project Conceptual Design, April, 1997. Further studies show that no facility modifications are required for high temperature operation. ${ }^{\mathrm{b}}$ Recent analysis (to be published) shows that the accident scenario for Bin Set \#1 would not exceed the evaluation guidelines for safety analysis. (For guidelines, see York, Cary, LMITCO, Letter to Robert M. Stallman, DOE-ID, INEEL RISK EVALUATION GUIDELINES - YORK-024-97, June 23, 1997)

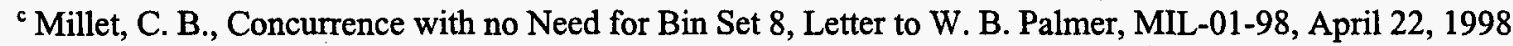




\section{FACILITIES AND PROCESSES}

The following existing radioactive waste treatment facilities are operational at ICPP. (DOE 1998) Liquid waste is stored in various interim storage tanks. These facilities and processes treat wastes to reduce the liquid volume, and to convert the liquid wastes to solids for continued interim storage.

\section{New Waste Calcining Facility (NWCF-CPP-659)}

The NWCF is a concrete and steel structure approximately $250 \mathrm{ft}$ long by $145 \mathrm{ft}$ wide and extends $57-\mathrm{ft}$ belowgrade and $43 \mathrm{ft}$ abovegrade located inside the ICPP fence. The NWCF converts radioactive liquid waste to a solid granular form. (ICPP 1998)

The Calcination Process. SBW is pumped by steam jet from the tank farm to the waste blend and hold tanks in the NWCF for temporary storage, sampling, and adjustment. Feed batches are prepared in the process makeup vessels in the NWCF by adjusting the SBW with aluminum nitrate, calcium nitrate, and boric acid. The liquid is fed into a hot, fluidized bed of solid particles where the water and other volatile compounds are flashed as vapor into the off-gas. The off-gas is cleaned and filtered before being released to the ICPP stack. Calcination occurs in the fluidized bed. Pressurized air atomizes the liquid feed solution through the feed nozzles. Process heat for calcination is provided by burning kerosene fuel with pure oxygen in the fluidized bed. During the process, bed level increases as particles grow from solids deposition and water flashes off as vapor. Particle attrition and bed withdrawal maintain the bed height at a steady, working level. Solids produced in the calcining process are pneumatically conveyed through a double-contained stainless steel line (encased in concrete) to solids storage bins.

The calciner processes liquid waste at a gross feed rate of about 180 gallons per hour. The scrub solution buildup, non-radioactive chemical additions, and non-processing downtime produce a net tank depletion rate of 30 to 80 gallons per hour.

- The continuing operation alternative would complete calcination of the SBW and would support waste management activities during tank farm closure.

- Orderly shutdown would immediately cease calcination of SBW. Process vessels would be emptied of waste solutions and solid product. Some decontamination rinses would be performed.

\section{ICPP HEPA Filter Leaching System (CPP-659)}

The high efficiency particulate air (HEPA) filters that are used in the off gas systems at ICPP are categorized as mixed waste because of the hazardous and radioactive components that are collected by the filter media. The filter leaching system uses chemical extraction to remove radionuclides and other hazardous constituents from used HEPA filters. The system treats both mixed waste and transuraniccontaminated waste. After leaching, the filters are ready for packaging for low level radioactive waste (LLW) disposal. The leachate generated by HEPA filter leaching is treated or stored in the ICPP liquid radioactive waste system.

- The continuing operation alternative would complete treatment of all spent HEPA filters. 
- Orderly shutdown would complete only those HEPA filters in process at the time of shutdown.

\section{NWCF Debris Treatment Facility (CPP-659). ${ }^{d}$}

The debris treatment area in the NWCF has decontamination cubicles, a spray booth, a decontamination cell, and a low-level decontamination room. Treatment technologies include water washing, chemical washing, high-pressure water and steam sprays, liquid abrasive spray, $\mathrm{CO}_{2}$ blasting and ultrasonic cleaning. Future plans include addition of secondary containment to the hot decontamination area for treatment of highly radioactive debris. The facility supports the ICPP waste operations by decontaminating equipment and tools for repair and reuse.

- Continuing operation of the Debris Treatment facility would support waste management activities until after the Tank Farm Closure.

- The orderly shutdown alternative would cease debris treatment.

\section{ICPP Process Equipment Waste (PEW) System}

Dilute radioactive liquid wastes are collected from the various facilities at ICPP in the PEW system. Waste is concentrated in the PEW evaporator (PEWE) after temporary storage in PEW tanks. The PEW is part of the ICPP liquid radioactive waste water treatment system. The system has collection vessels, feed tanks, thermosyphon evaporators, instrumentation, and controls.

The PEW has four 4500 gal collection tanks in CPP-601 (WG-100, -101, WH-100, -101). Wastes are pumped from the collection tanks through underground lines to the PEWE feed tanks in CPP-604. Each feed tank has a capacity of 18,400 gallons. There are two steam heated thermosyphon evaporators with a heat transfer capacity of 3.25 million Btu/h each. The concentrated waste from the bottom of the evaporator is transferred to the tank farm. The condensate from the overhead vapors goes to the Liquid Effluent Treatment and Disposal (LET\&D) for further treatment

- Continuing operation of the PEW system would support waste management activities until after the Tank Farm Closure.

- The orderly shutdown alternative would cease operation of the PEW.

\section{Liquid Effluent Treatment and Disposal (LET\&D)}

The LET\&D building is a steel-frame metal-sided building $21 \mathrm{~m}(68 \mathrm{ft})$ by $10 \mathrm{~m}(34 \mathrm{ft})$ by $16 \mathrm{~m}(53 \mathrm{ft})$ high within the ICPP fence. Process equipment includes acid fractionators, reboilers, condensers, separators, bottoms coolers, feed tank, and bottoms tank. The off gas system includes HEPA filters,

\footnotetext{
dProject Design Criteria for CPP-659 New Waste Calcining Facility Debris Rule Compliance Project, Rev 1, March 31, 1997
} 
blowers, and superheaters. A distributed control system (DCS) monitors and controls the process.

The two main processes occurring in the LET\&D are complexing and acid fractionation. Complexing involves the chemical bonding of the fluoride ion to the aluminum ion. The fluoride ion in some of the liquid waste is very corrosive when concentrated and heated. Aluminum is used to chemically bond the fluoride ion to reduce its corrosive action on equipment. Acid fractionation concentrates nitric acid and distills most of the water off as steam. The water vapor is heated, filtered through HEPA filters, and exhausted to the ICPP stack. The LET\&D facility eliminates the liquid volume of the PEWE condensates that otherwise would be routed to service waste and the percolation pond. The bottoms from the LET\&D are recycled to NWCF or sent to the ICPP Tank Farm for storage pending final treatment. (ICPP 1992)

- Continuing operation of the LET\&D would support waste management activities until after the Tank Farm Closure.

- The orderly shutdown alternative would cease operation of the LET\&D.

\section{ICPP Tank Farm}

Interim storage space for radioactive liquid waste before calcination is provided by eleven 300,000 -gal underground tanks (WM-180 to -190). Each of the 300,000-gal liquid waste storage tanks is totally enclosed inside an underground concrete vault. The tanks do not comply with RCRA storage requirements. (Palmer et. al. 1998; Spaulding 1998)

SBW can be jetted (pumped) from any of the 300,000-gal waste tanks to the NWCF for solidification. Waste can also be transferred between tanks in the tank farm. Tank contents are generally segregated according to composition for proper adjustment during calcination. (ICPP 1996a)

- Continuing operation of the tank farm and related radioactive waste systems would empty the tank farm and close to RCRA landfill standards. Three new RCRA permitted tanks would be constructed and operated.

- The orderly shutdown alternative would not empty nor close the tank farm.

\section{High-Level Liquid Waste Evaporator (HLLWE)}

The HLLWE, located in the blend and hold cell of the NWCF, is used to concentrate selected tank farm solutions to the nominal specific gravity of 1.3. The HLLWE reduces the volume of waste to be stored or calcined. Liquid waste volume can be reduced faster and at lower cost in the HLLWE than in the NWCF. The HLLWE handles feed from the Tank Farm and is able to run independently of calciner operations. The evaporator is steam heated. The concentrated bottoms are sent to the tank farm; the condensate is sent to the LET\&D for further treatment.

\section{Calcine Solids Storage Facilities (CSSF)}

There are seven CSSFs, each with four to seven stainless steel bins. Each bin set is enclosed in a 
concrete vault. The stainless steel bins are designed for interim storage of calcine solids for up to 500 years. (Hoffman 1975) The first through fifth CSSFs are filled to operating capacity. The sixth CSSF is receiving the calcine from the current NWCF campaign. The seventh CSSF is empty and available for future NWCF campaigns.

A detailed inventory of the calcined waste in storage in the ICPP CSSFs was prepared from an examination of calciner startup data, waste solution calcination records, calcine solids storage bin data, and other operational records. The calcined solids in the bins consist of mixed-metal oxides and fluorides containing Sr-90, Cs-137, and transuranics.

Table 1. Inventory of the CSSF bin sets as of February 1998

\begin{tabular}{|c|c|c|c|c|}
\hline $\begin{array}{c}\text { CSSF } \\
\text { Bin } \\
\text { Set }\end{array}$ & $\begin{array}{c}\text { Reference for } \\
\text { Description }\end{array}$ & $\begin{array}{c}\text { Total } \\
\text { capacity } \\
\mathbf{f t}^{\mathbf{3}}\end{array}$ & $\begin{array}{c}\text { Usable } \\
\text { volume } \\
\mathbf{f t}^{\mathbf{3}}\end{array}$ & $\begin{array}{c}\text { Filled contents } \\
\mathbf{f t}^{\mathbf{3}}\end{array}$ \\
\hline 1 & ICPP 1996b & 8300 & 8000 & 7650 \\
\hline 2 & ICPP 1994a & 31600 & 30200 & 30200 \\
\hline 3 & ICPP 1994a & 40000 & 38700 & 38500 \\
\hline 4 & $\begin{array}{c}\text { Schindler 1980; } \\
\text { ICPP 1994b }\end{array}$ & 17700 & 17200 & 17200 \\
\hline 5 & ICPP 1984 & 36200 & 35000 & 35000 \\
\hline 6 & ICPP 1997 & 55200 & 53200 & 5800 \\
\hline 7 & Mozes 1985 & 63,000 & 63,000 & 0 \\
\hline
\end{tabular}

\section{Gaseous Waste Systems}

Gaseous waste systems support the operation of the HLW facilities by treating, monitoring, and releasing process off gas and ventilation air to the atmosphere. (ICPP 1996c)

The Atmospheric Protection System (APS) and Main Stack Gaseous waste is filtered and released through the APS and the ICPP main stack. The APS provides final filtration for several process off gas and ventilation systems before release to the environment.

The ICPP Main Stack is a 250 -ft tall concrete structure lined with stainless steel. The inside diameter of the stack is a uniform 8-ft tapering to $6.5 \mathrm{ft}$ at the very top. The main stack (CPP-708) is the final release and monitoring point for ventilation air and process off-gas that has been filtered by the APS. An isokinetic sample and analysis system monitors the stack effluent. The sample line withdraws a sample from a probe located $90 \mathrm{ft}$ above the base of the stack. The sample flow is proportional to the main stack flow

${ }^{\mathrm{e}}$ M. D. Staiger, Review of Calcined High-Level Waste Stored at the ICPP (To Be Published April 1998) 


\section{Support Facilities}

Infrastructure and support facilities provide utilities and support services for waste operations. A remote analytical laboratory, utilities, maintenance and office buildings, and security systems are operational. (ICPP 1980; ICPP 1994) 


\section{DESCRIPTION OF THE NO-ACTION ALTERNATIVES}

\section{Continuing Operation}

Normal operation of the ICPP process and support facilities will continue as planned and budgeted for radioactive waste treatment and storage. The ICPP manages several types of radioactive waste: calcined solid waste, SBW, debris, and HEPA filters. These wastes are considered mixed waste because they contain hazardous components regulated under RCRA.

The NWCF will continue to operate until 2012 to empty the tank farm. Newly generated waste will be concentrated by the HLLWE, to minimize stored volume, and collected in new RCRA compliant tanks after 1012. The NWCF offgas cleanup system will be modified to control emission at or below the levels required by EPA's proposed Maximum Achievable Control Technology (MACT) rule. The operation with MACT will receive an operating permit. The calcine material will remain in storage in the CSSF bin sets. Other currently used waste management facilities will continue in operation or surveillance.

\section{Continuing operation - calcination of SBW in the NWCF.}

Calcination is a proven ICPP Process that uses high temperatures to convert liquid waste into a granular solid. Liquid wastes are sprayed into a hot $\left(500\right.$ to $\left.600^{\circ} \mathrm{C}\right)$, air-fluidized bed of granular solids where volatile components are flashed and the metallic salts are converted to oxides. The calciner of-gas is passed through a cyclone, where most of the entrained fine particles are settled out. The fine particles are combined with the larger solids that are removed by the product take-off lines. The solids are transported by air entrainment to the CSSF for storage. Transport air is returned to the calciner. Calciner off-gas is treated by passing it through a quench tower, venturi scrubber and demister. The quench tower is used to cool the off-gas and remove moisture and solid particles. The resulting scrub solution is continually recirculated through the quench tower and venturi scrubber and is eventually recycled back to the feed system and processed in the calciner. The off-gas then passes through silica gel beds, demister, superheater, HEPA filters and is exhausted to the Atmospheric Protection System (APS), which exhausts to the main stack.

Calcination greatly reduces the volume of stored radioactive waste. Converting radioactive liquid waste to solid calcined waste minimizes the amount of storage space required. Risks to the environment are significantly decreased by removing liquid wastes from the tank farm and putting them in a less corrosive, less mobile form (calcine). Aluminum nitrate, calcium nitrate, and boric acid are added to the calciner for proper operation of the process. Aluminum nitrate ensures that $\mathrm{Na}+\mathrm{K}$ mol\% of the calcine produced does not cause bed agglomeration. Calcium nitrate reduces volatilization of fluorides, chlorides, sulfates and phosphates. Boric acid is added to limit the formation of insoluble alpha alumina during calcination. (Murphy 1995)

The Decontamination Facility. Thedecontamination and debris treatment area in the NWCF Building (CPP-659 will continue in operation until 2020 to support ongoing waste storage and treatment operations. reduce personnel radiation exposures; 2) preclude contaminant spread from work areas; 3 ) provide newer, more efficient and effective decontamination techniques; and 4) treat mixed hazardous waste for disposal. The area has an ultrasonic cleaner, two sinks with ventilation hoods, decontamination 
solution makeup tanks and transfer pumps. There is a shielded storage box and a shielded area

NWCF Process Control Modification. After approval of the safety analysis report, the calciner temperature control will be changed to $600^{\circ} \mathrm{C}$. The higher temperature will limit bed agglomeration with smaller amounts of added aluminum nitrate. A MACT facility is planned that will modify the off gas emissions to meet the MACT standards. The calciner will be permitted as a waste treatment facility.

NWCF Shutdown and Standby. As the calciner completes the calcination of SBW, several batches of low activity waste will be calcined. Use of low activity feed will reduce the residual contamination in the process equipment. Further decontamination can be achieved by feeding unirradiated batches of aluminum nitrate to produce non-radioactive aluminum oxide solids. Transfer of non-radioactive solids to the CSSF would clean some of the residual contamination in the solids transport line. The success of these decontamination efforts would be monitored by the decreasing level of activity in the off-gas scrub solution. When the desired lower level of contamination is reached, the liquid feed and fuel would be stopped, and the solid calciner bed would be removed to the CSSF. The calciner would be placed in standby in that condition. No chemical rinses that would produce additional radioactive liquid waste would be used. The blowers would be turned off and the ventilation dampers would be closed. The building and process equipment would be stable and would contain radioactive contamination for indefinite, extended periods.

\section{Continuing operation - Tank Farm}

Tank Farm Operation. The tank farm will continue to receive concentrated radioactive waste from the operation of the HLLWE and the PEWE. Liquid SBW and concentrated wastes in the tank farm will continue to be fed to the NWCF until the installed piping could no longer remove solution. Dilute waste such as water from the fuel storage basins will be used to dilute the residual liquid heel in each of the tanks. Tank contents will be sequentially transferred from one tank through the next one to continually reduce the concentration of hazardous and radioactive components in the heels. The HLLWE will be operated to concentrate the dilute tank farm solutions for feed to the NWCF.

Six storage tanks (WM-180, -181, -183, -184, -185, and -186) currently contain SBW with an average calculated radionuclide activity of $0.18 \mathrm{Ci} / \mathrm{L}$ (decayed to 2016). ${ }^{f}$ The other 5 storage tanks contain heels from earlier HLW operations.

Table 2. Tank Farm Volumes (Gallons, as of March 31, 1998)

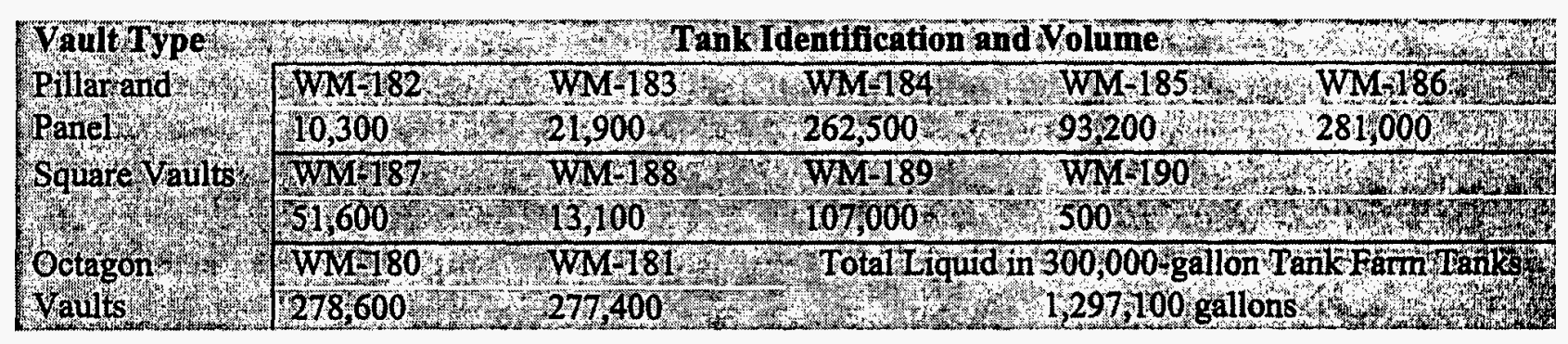

\footnotetext{
f Reference: Wenzel, D. R., Calculation of Radionuclide Inventories for Sodium Bearing Wastes, Letter to N. E. Russell, Wen-23-97, November 26, 1997
} 
Tank Farm Closure. The tanks will be emptied down to the lowest level achievable by the installed piping systems. Additional sump pumps will be placed in the tanks to further reduce the residual liquid heel. The concentration of the waste will be reduced by rinsing with clean water. The waste solutions will be processed by the NWCF. Spaulding (1998) estimated a cease use and closure sequence for the eleven tanks. The small remaining tank heels will be solidified in place in the tanks by the addition of grout. After the heels are solidified, the tanks and vaults will be filled with grout for RCRA landfill closure.(Spaulding 1998)

\section{Continuing operation - Liquid Waste Systems.}

LET\&D. The ICPP LET\&D will continue to reduce the PEWE condensate liquid volume. The process reduces the volume of the PEWE condensate liquid by distillation and concentrates the nitric acid. The concentrated bottoms will be sent to the tank farm for storage or directly to the NWCF for use in the calciner off-gas scrub. The vapor will continue to be exhausted to the ICPP stack.

PEW. The PEW system will continue to receive contaminated liquid waste from ICPP operations. The PEWE will continue to concentrate the dilute waste. The condensate from the evaporator will be sent to the LET\&D for further treatment and the concentrated bottoms will be sent to the tank farm.

\section{The Calcined Solids Storage Facilities Continuing Operation.}

The calcined solids from the SBW calcination by the NWCF will be sent to the sixth and seventh CSSF. The CSSF operation is managed in conjunction with the NWCF operation. Calcined solids fill the bins in the CSSF as the transport air flows from the NWCF. The solids are disengaged from the transport air in the cyclone separator near the top of the CSSF. The transport air returns to the NWCF for filtration and release. When the NWCF shuts down, the CSSF is placed in standby and monitoring mode.

\section{Operating Cost Estimate}

Operating cost estimates for the no action alternative are based on operating experience at ICPP. Project costs will be refined as detailed designs are developed for construction. Operating costs continue to be validated by review, efficiency improvements, and experience. (DOE 1998) 
Table 3 Continuing Operation Cost Estimate

\begin{tabular}{|c|c|c|c|}
\hline Facility & $\begin{array}{l}\text { FY } 2000 \\
\text { Estimate }\end{array}$ & $\begin{array}{l}\text { FY } 2000 \text { to } 2020 \\
\text { Estimate }\end{array}$ & Other \\
\hline $\begin{array}{l}\text { Liquid Waste Systems } \\
\text { (PEW, LET\&D, SW, Stack) }\end{array}$ & $\$ 8,030,000$ & $\$ 168,630,000$ & Inactivated in 2020 \\
\hline Liquid Waste Systems Utilities & $\$ 1,300,000$ & $\$ 24,717,000$ & Zero after 2020 \\
\hline Calciner Operation & $\$ 12,883,000$ & $\$ 256,748,000$ & Shutdown after 2020 \\
\hline Calciner Utilities & $\$ 2,105,000$ & $\$ 39,018,000$ & Zero after 2020 \\
\hline Calciner Modifications (Operating) & $\$ 3,238,000$ & $\$ 25,338,000$ & None after 2020 \\
\hline Calciner Modifications (Capital) & $\$ 10,550,000$ & $\$ 70,250,000$ & Zero after 2020 \\
\hline CSSF Bin Sets Operation & $\$ 271,000$ & $\$ 5,691,000$ & $\begin{array}{l}\$ 21,680,000 \text { for } 80 \\
\text { additional years of } \\
\text { institutional control. }\end{array}$ \\
\hline CSSF Utilities & $\$ 60,000$ & $\$ 1,302,000$ & $\begin{array}{l}\text { Included in institutional } \\
\text { control after } 2020 .\end{array}$ \\
\hline Administration \& Oversight & $\$ 6,013,000$ & $\$ 122,094,000$ & $\begin{array}{l}\text { Covered in } 80 \text { years of } \\
\text { institutional control. }\end{array}$ \\
\hline Technology Development & $\$ 6,664,000$ & $\$ 96,074,000$ & None after 2020 \\
\hline Support Facilities Utilities & $\$ 2,300,000$ & $\$ 48,300,000$ & Zero after 2020 \\
\hline Tank Farm Operation & $\$ 2,688,000$ & $\$ 52,285,000$ & Tank farm closed \\
\hline Tank Farm Utilities & $\$ 430,000$ & $\$ 9,114,000$ & Zero after 2020 \\
\hline Tank Farm Addition (Capital) & 0 & $\$ 138,390,000$ & Closed after 2020 \\
\hline $\begin{array}{l}\text { Tank Farm Closure (Spaulding } \\
\text { 1998) }\end{array}$ & & $\$ 90,700,000$ & $\begin{array}{l}\text { Assumes conceptual design } \\
\text { begins in FY } 2000 .\end{array}$ \\
\hline Sub-Total & $\$ 56,532,000$ & $\$ 1,148,651,000$ & $\$ 21,680,000$ \\
\hline Total & & & $\$ 1,170,331,000$ \\
\hline
\end{tabular}

\section{Orderly Shutdown}

Orderly shutdown will begin immediately upon notification and direction to shutdown. A detailed plan for the sequence of shutdown will be prepared. Criteria for completion of shutdown will be established.

The collection and feed tanks for each of the evaporators will be processed and flushed. The bottoms collection tanks will be transferred to the tank farm. The LET\&D feed tanks will be processed, the bottoms collection tanks will be transferred forward through the normal path. The calciner makeup and feed tanks will be processed through the calciner. Several batches of unirradiated aluminum nitrate feed solution will be processed through the calciner to convert the bed to unirradiated solids. The scrub solution will be changed out several times during the last batches to flush radioactivity forward. The final bed will be cooled and transferred to the CSSF. The unirradiated feed batches will produce solids with much lower radioactivity than normal operational batches. The final batch transferred will scour the product transfer line and reduce the background and contamination levels. After the NWCF solids bed is transferred, the bed will be collapsed and left in place.

Inflow of all waste streams will be shut off. Valves will be closed and selected lines will be cut and 
capped. The instrumentation, off gas blowers, and building HVAC systems will be shut down. Main power breakers will be disconnected. The main ICPP stack blowers will be shut down. Facility inlet dampers will be closed.

The tank farm will be left with large inventories of radioactive liquid.

Operating Costs. All waste facilities would be operational until the last one is shutdown for continuity of integrated operation. One year of operation would be required at an estimated cost of $\$ 36,080,000$.

Consequences. All facilities would contain hazardous and radioactive material. Structure condition would degrade. Building roofs would leak. Facility liquid sump would accumulate liquid up to some steady state level. Evaporation and leakage to ground would limit the amount of accumulation. Tanks would develop leaks eventually. The worst case leak would be that of a tank farm tank full of SBW. The environmental consequence of a catastrophic tank failure has been analyzed in the safety analysis report. Off site consequences would be 2 mrem CEDE after 100 years from drinking water. The airborne consequence would be one mrem TEDE at the site boundary within that period.

The CSSF contents are expected to remain stable for 500 years. After 500 years, the remaining hazardous constituents will be mostly transuranic isotopes and heavy metals. Institutional control would cease at the completion of shutdown. Site security will limit public access.

Penalties would be imposed for violation of the settlement agreement and RCRA regulations. 
$140 f 31$ 


\section{PROJECTS}

Projects are planned that will improve the operation of the ICPP waste treatment and storage facilities. Continued operation after planned improvements will support waste storage, treatment, and disposal. NWCF operation will continue after a permit is granted. The tank farm will be RCRA closed by 2020 .

\section{Electrical and Utility System Upgrade Project}

The ICPP Electrical and Utility System Upgrade Project is not considered part of the no action alternative. However, it is currently implemented and will be completed as planned to support all activities at ICPP. The total life-cycle cost associated with this project is $\$ 56$ million. Construction completion is scheduled for December $2001 .^{\mathrm{g}}$

\section{NWCF modifications for the MACT rule.}

A new facility, called the MACT Compliance Facility (MCF), is to be constructed adjacent to the NWCF near the ICPP main stack to house the MACT control equipment. The MCF will be a high bay building approximately $46 \times 108 \times 40 \mathrm{ft}$. No significant environmental impacts were identified for construction activities or operations. The MCF will be constructed within the ICPP fence on an area in which the soil has been extensively disturbed during previous ICPP construction and operational activities. (Rawlins 1997).

The MACT rule imposes strict limits for the emission of (a) dioxins/furans, (b) hydrocarbons, (c) carbon monoxide, (d) particulate matter, (e) mercury, (f) semivolatile metals (i.e., lead and cadmium, (g) lowvolatile metals (i.e., antimony, arsenic, beryllium, and chromium), and (h) hydrogen chloride/chlorine.

During the MCF operation, additional fuel for the secondary burner system will be used. Maintenance activities will be similar to existing activities at the ICPP. One new operator for each shift will be required to operate and maintain the new equipment. Increases in the use of water and electrical power and generation of wastewater and miscellaneous solid waste will be minimal. Over the life of the facility, approximately $28.3 \mathrm{~m}^{3}\left(1000 \mathrm{ft}^{3}\right)$ of granulated activated carbon containing $2,630 \mathrm{~kg}(5,800 \mathrm{lb})$ of mercury will require processing.

The MCF will be placed in standby, shutdown upon completion of NWCF operation. Environmental and regulatory concerns will be further evaluated during the project execution. The modification is based on the assumption that the MACT rule as proposed will be a requirement for an operating permit. (62FR75 1997)

The system proposed for the MCF includes a multistage combustion process to treat $\mathrm{CO}$, THC, dioxins, furans, and $\mathrm{NO}_{\mathrm{x}}$; a water spray quench for off-gas temperature control, a demister, a heater, a sulfurimpregnated granular activated carbon $\mathrm{Hg}$ removal system, a heater, HEPA filters, blowers, and a continuous emissions monitoring system.

${ }^{8}$ INEEL, Accelerating Cleanup: Paths to Closure, Idaho Operations Office, PLN-177, Appendix A, Page Project ID-OIM-106, February 1998 


\section{Radioactive Liquid Waste Tanks}

New radioactive liquid waste tanks will be required as part of the continuing operation to support the waste storage, treatment, and disposal operations at ICPP. All of the waste treatment facilities depend on available storage tanks to handle in-process waste solutions. Three new tanks and a containment vault will be constructed and permitted for operation until after all liquid waste facilities have shut down. The tanks will accumulate and store batches of waste solutions from the PEWE, the HLLWE, the LET\&D, the NWCF, the spent nuclear fuel storage facilities, and other waste generators. The tanks will be closed and decommissioned after closure of the old tank farm facility.

\section{Basis for the MACT Project Data Sheet}

General Project Objective The general purpose of the MACT Compliance Facility is to install the modifications in the New Waste Calcining Facility (NWCF) that would be required to control the off-gas emissions at or below the levels required by the Environmental Protection Agency's (EPA's) proposed MACT rule. The necessity for the MACT Compliance Facility is based on the assumption that the MACT rule will be applied to the NWCF permit to operate when implemented.

Summary of Impacts No significant environmental impacts were identified for construction activities or operations. The MCF will be constructed within the ICPP fence on an area in which the soil has been extensively disturbed during previous ICPP construction and operational activities. Maintenance activities and exposures will be similar to those currently required for the existing APS. Local contractors will accomplish construction work. Only limited construction personnel will be brought in from other areas to support the construction. No impacts to local schools or communities are expected. During the MCF operation, additional fuel (kerosene) for the secondary burner system will be brought to the ICPP area. Routine maintenance activities will be required to service filters, perform preventive maintenance on equipment, and change out carbon adsorbers. These maintenance activities are similar to existing activities at the ICPP and will be accomplished using approved written procedures. One new operator each shift will be required to operate and maintain the new equipment. Increases in the use of water and electrical power and generation of wastewater and miscellaneous solid waste will be minimal. The filter media, carbon, and material collected by these devices will be disposed of using approved procedures. Over the life of the facility, a total of approximately $28.3 \mathrm{~m}^{3}\left(1,000 \mathrm{ft}^{3}\right)$ of granulated activated carbon containing $2,630 \mathrm{~kg}(5,800 \mathrm{lb})$ of mercury will require processing. Procedures exist for leaching and disposing of the high-efficiency particulate air filter elements, but new processes will have to be put into place for removing the mercury from the carbon and processing the mercury to stabilize it. 
Table 4. Project data sheet for NWCF MACT Compliance Facility.

\section{Generic Information}

Description/function:

of

EIS alter. (A, B, etc.): No Action

Project Type or waste stream:

Action type:

Structure type:

Size, $\mathrm{m}^{3}$ :

Other features:

Location:

Inside/outside of fence

Inside/outside of building

MACT Compliant Off-gas Treatment System

NWCF

Separations - 2006

Non-Separations - Vitrified waste

- HIPed Waste

- Direct Cementitious

Calciner off-gas

New

Steel frame

$5,675 \mathrm{~m}^{3}$ (108 ft x $\left.46 \mathrm{ft} \times 40 \mathrm{ft}\right)$

Kerosene fuel tanks $(57,000 \mathrm{~L}$ each)

Inside ICPP fence

Inside of MACT Compliance Facility

Construction Information

Cost (\$): Preconstruction:

Conceptual Design

$\$ 3,400,000$

Management Costs

$2,500,000$

Project Development

$2,700,000$

$2,500,000$

Permitting and Documentation

$10,700,000$

SO Test and Start-Up

$\$ 22,100,000$

Cost (\$): Construction:

ED\&I

$\$ 8,700,000$

Management (PM/CM)

$6,800,000$

Construction

$21,900,000$

G\&A/PIF

$2,800,000$

Procurement Fees, Mgmt Reserve, and Contingency

$14,500,000$

Total Construction (TEC)

$\$ 54,700,000$

Schedule start/end: Preconstruction

January, 1999 through December, 2001

Schedule start/end: Construction

January, 2002 through December, 2006

Schedule start/end: SO Test \& Start-up

January, 2007 through December, 2007 
Table 4. (Continued.) Project data sheet for NWCF MACT Compliance Facility.

Number of workers each year of construction (new/existing)

Nonradiation

48 New workers/yr

Number of radiation workers (construction)

none

Average Annual worker radiation dose (rem/yr)

none

\section{Heavy equipment}

Equipment used

Dump trucks/flatbeds

Trips:

$15010-\mathrm{km}$ round trips to spoil area;

50 12-mi round trips to RWMC;

20 trips for equipment and supplies

Hours of operation (including materials delivery vehicles)

1320 hours (total)

Acres disturbed and duration of disturbance

January 1999 through December 2012

New

None

Previous

3.4 acres

Revegetated

0

\section{Air emissions}

Dust

9 tons (total)

Major gases $\left(\mathrm{CO}_{2}, \mathrm{H}_{2} \mathrm{O}, \mathrm{O}_{2}, \mathrm{~N}_{2}\right)$ from diesel exhaust

1,134 tons (total)

Contaminants (Particulates, $\mathrm{CO}, \mathrm{NO}_{\mathrm{x}}, \mathrm{SO}_{2}$,

hydrocarbons) from diesel exhaust

3 tons (total)

SO testing air emissions (trace $\mathrm{SO}_{\mathrm{x}}, \mathrm{NO}_{2}$ )

Total air emissions

$$
2 \text { tons (total) }
$$

1,148 tons (total)

Effluents

SO testing process wastewater (non-radioactive)

9,000 liters (total)

Sanitary wastewater

none

Lube Oil

negligible

\section{Solid wastes}

Type - Miscellaneous low-level waste

$15 \mathrm{~m}^{3}$ (total)

Type - Miscellaneous industrial waste

$7 \mathrm{~m}^{3}$ (total) 
Table 4. (Continued.)Project data sheet for NWCF MACT Compliance Facility.

\section{Water usage}

Dust control

230,000 liters (total)

SO testing process water (quench cooling)

$14,400,000$ liters (total)

Domestic water (construction and SO testing)

negligible

Hazardous/toxic chemicals and wastes

Storage/inventory

none

Pits/Ponds created $\left(\mathrm{m}^{2}\right)$

none

Hazardous waste (SO Testing ...HEPA filters)

$1 \mathrm{~m}^{3}$ (total)

Hazardous waste (construction)

$1 \mathrm{~m}^{3}$ (total)

\section{Energy requirements}

Electrical (MWh/yr)

$5 \mathrm{MWh} / \mathrm{yr}$

Fossil fuel (liters)

Permits needed for construction

10,000 liters (total)

NEPA documentation (prior to start of Title II design); facility operations will be included with NWCF operating permit.

Operational Information

Cost (\$): Operations

Facility/Administration

$\$ 750,000$

Operations/Process Facility

$2,340,000$

Procurement, materials, utilities, maintenance

$7,810,000$

Total operations

$$
\$ 10,900,000
$$

Schedule start/end

January, 2008 through December, 2012

Number of workers each year of operation (new/existing)

Operations

\section{4}

Maintenance

Support

Total

Number of radiation workers

Average annual work radiation dose (rem/yr)

Heavy Equipment
3

1

8

4 included in above

$0.1 \mathrm{rem}$

none 
Table 4. (Continued.)Project data sheet for NWCF MACT Compliance Facility.

Air Emissions

Radioactive off-gas

\section{Effluents}

Sanitary Wastewater

Process water (once-through cooling water)

Decontamination solution (nitric acid)

\section{Solid Wastes}

Sanitary/Industrial Trash

Radioactive wastes (canisters, amalgam)

Hazardous/toxic chemicals and wastes

Pits/Ponds used $\left(\mathrm{m}^{2}\right)$

Spent Carbon (mixed waste)

Misc. hazardous waste

\section{Water usage}

Process water (quench cooling water)

Domestic water

\section{Energy Requirements}

Electrical

Steam

Fossil fuel (liters/yr)

Permits needed (for facility operations) minimal

none

1,471,680 liters/yr.

none

$$
\begin{aligned}
& 25 \mathrm{~m}^{3} / \mathrm{yr} \text {. } \\
& \text { negligible }
\end{aligned}
$$

none

$7 \mathrm{~m}^{3} / \mathrm{yr}$.

$5 \mathrm{~m}^{3} / \mathrm{yr}$.

$1,471,680$ liters/yr.

none

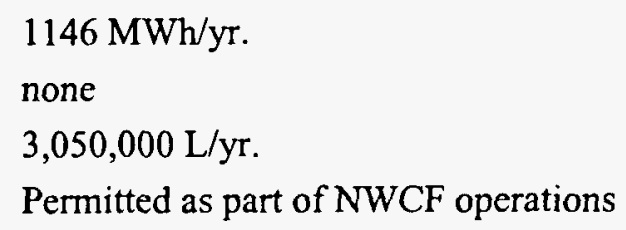


Table 4. (Continued.)Project data sheet for NWCF MACT Compliance Facility.

Decontamination \& Decommissioning (D\&D) Information

Cost (\$): D\&D

Decommission

Decontamination

Demolition

Total D\&D

Schedule start/end: D\&D

Number of workers each year of D\&D (new/existing)

Number of radiation workers (D\&D)

Average annual worker radiation dose (rem/yr)

\section{Heavy equipment}

Equipment used

Trips Trucks

Hours of operation (all heavy equipment)

Acres disturbed and duration of disturbance

New

Previous

Revegetated

\section{Air emissions}

Non-radioactive Fuel combustion gases $\left(\mathrm{CO}_{2}, \mathrm{H}_{2} \mathrm{O}, \mathrm{O}_{2}\right.$,

$\mathrm{N}_{2}$ )

Non-radioactive Fuel combustion contaminants $(\mathrm{CO}$, particulates, $\mathrm{NO}_{x}, \mathrm{SO}_{2}$, hydrocarbons)

Radioactive HEPA filtered off-gas

\section{Effluents}

Radioactive spent decontamination solution

Non-radioactive sanitary wastewater

Non-radioactive lube oil
$\$ 200,000$

500,000

$3,000,000$

$\$ 3,700,000$

January, 2013 through December, 2014

12

12 included in the above

$0.1 \mathrm{rem}$

Mobile Cranes, Trucks, Dozers, Loaders 1 per day

10,500 hours (total)

none

3.4 acres

none

6,000 tons (total)

35 tons

negligible

35,000 liters trace contamination

110,000 liters

negligible 
Table 4. (Continued.)Project data sheet for NWCF MACT Compliance Facility.

\section{Solid wastes}

Radioactive

Non-radioactive (industrial)

Hazardous

$$
\begin{gathered}
2,900 \mathrm{~m}^{3} \text { (total) } \\
2,300 \mathrm{~m}^{3} \\
10 \mathrm{~m}^{3}
\end{gathered}
$$

Hazardous/toxic chemicals and wastes (type)

Storage/inventory

none

Pits/ponds created $\left(\mathrm{m}^{2}\right)$

none

Radioactive (mixed waste)

$1 \mathrm{~m}^{3}$ total

Water usage

Process water

1500 liters

Domestic Water none

Source of water

ICPP site wells

\section{Energy requirements}

Electrical (MWh/yr)

Fossil fuel (liters)

Permits needed (e.g. for facility closures, physical characteristics and quantities of radioactive and Hazardous materials remaining after closure)

$5 \mathrm{MWh} / \mathrm{yr}$. 45,000 liters Work will be done under closure provisions of existing permits. 


\section{Basis for the Radioactive Liquid Waste Tanks Data Sheet}

General Project Objective The general purpose of the Radioactive Liquid Waste Tanks is to provide a permitted storage facility for interim storage of radioactive liquid waste at the ICPP. The necessity for the Radioactive Liquid Waste Tank Facility is based on the assumption that a permitted facility will be required to support the NWCF operation for calcination of the SBW and for tank farm closure.

Summary of Impacts No significant environmental impacts were identified for construction activities or operations. The Radioactive Liquid Waste Tanks will be constructed within the ICPP fence on an area in which the soil has been extensively disturbed during previous ICPP construction and operational activities. Maintenance activities and exposures will be similar to those currently required for the existing tank farm. Local contractors will accomplish construction work. Only limited construction personnel will be brought in from other areas to support the construction. No impacts to local schools or communities are expected. Routine maintenance activities will be required to repair failed valves and perform preventive maintenance on equipment. These maintenance activities are similar to existing activities at the ICPP and will be accomplished using approved written procedures. Existing operators on shift assignment will operate and maintain the new tanks. There will be no increases in the use of water and electrical power and generation of wastewater and miscellaneous solid waste. 
Table 5. Project Data Sheet for Radioactive Liquid Waste Tanks

\section{General Information}

Description/Function:

EIS Alternative

Project Type:

Waste Stream:

Action Type:

Structure Type:

Size, $\mathrm{m}^{3}$ :

Other Features

Location:

Inside/outside of fence

Inside/outside of building

Candidate for privatization?:

Construction Information

Cost (\$): Preconstruction

Feasibility Study

Conceptual Design

Project Support

SO Test and Start-Up

Total Preconstruction

Cost (\$): Construction

ED\&I

Management (PM/CM)

Construction

G\&A/PIF

Procurement Fees, Mgmt Reserve, and Contingency

Total Construction (TEC)

Schedule start/end: Preconstruction

Schedule start/end: Construction

Schedule start/end: SO Test \& Startup

Number of workers (new/existing)

Nonradiation

Number of radiation workers (Construction)

Average annual worker radiation dose (rem/yr)
New Radioactive Waste Collection Tanks

No-Action Continuing Operation

Waste Management Program

SBW, MLLW

New

Underground Vault

$5060(50 \mathrm{ft}$ X $148 \mathrm{ft} \times 25 \mathrm{ft})$

Three new underground Storage tanks

(100,000-gallon capacity per tank) Concrete vault, liner, leak detection, piping for transfes and vents. Tie-in to existing systems.

Inside of ICPP fence

N/A

No

$\$ 1,142,000$

$\$ 3,630,000$

$\$ 10,795,000$

$\$ 2,931,000$

$\$ 18,498,000$

$\$ 13,436,000$

$\$ 7,086,000$

$\$ 65,337,000$

$\$ 16,162,000$

$\$ 36,369,000$

$\$ 138,390,000$

January, 2001 through December, 2004

January, 2005 through December, 2009

October, 2008 through September, 2010

20

none

$0.1 \mathrm{rem}$ 
Table 5. (Continued) Project Data Sheet for Radioactive Liquid Waste Tanks

\section{Construction Information (Continued)}

Heavy Equipment

Equipment used

Trips

Hours of operation

Acres disturbed and duration of disturbances

New

Previous

Revegetated

\section{Air Emissions}

Dust

Major gases $\left(\mathrm{CO}_{2}, \mathrm{H}_{2} 0, \mathrm{O}_{2}, \mathrm{~N}_{2}\right.$, ) from diesel exhaust

Contaminants (Particulates, $\mathrm{CO}, \mathrm{No}_{\mathrm{x}}, \mathrm{SO}_{2}$, hydrocarbons( from diesel exhaust

SO testing air emissions

Total air emissions

\section{Effluents}

SO testing process wastewater (non-radioactive

Sanitary wastewater

Lube Oil
Excavator, scrapers, trucks, cranes, cement trucks

40 to bring equipment and materials to site. 200 to spoil area

4,000

January, 2005 through September, 2037

None

4 acres

0

20 Tons (total)

1500 tons (total)

3.5 tons (total)

Negligible

1524 tons (total)

20,000,000 liters (total)

None

Negligible 
Table 5 (Continued) Project Data Sheet for Radioactive Liquid Waste Tanks

\section{Construction Information (Continued)}

Solid wastes

Type - Miscellaneous low-level waste

$500 \mathrm{~m}^{3}$ (contaminated soil)

Type - Miscellaneous industrial waste

$10 \mathrm{~m}^{3}$ (total)

Water usage

Dust control

300,000 liters (total)

SO testing

20,000,000 liters (total)

Domestic water (construction and SO testing)

Negligible

Hazardous/toxic chemicals and wastes

Storage/inventory

None

Pits/Ponds created $\left(\mathrm{m}^{2}\right)$

None

Hazardous waste (SO test)

None

Hazardous waste (construction)

$0.5 \mathrm{~m}^{3}$ (total)

\section{Energy requirements}

Electrical (MWh/yr)

Fossil fuel (liters

Permits needed for construction

$7 \mathrm{MWh} / \mathrm{yr}$

45,500 liters (total)

NEPA documentation (prior to start of Title ] design); RCRA hazardous waste storage facility operating permit submitted 180 days prior to start of construction

\section{Operational Information}

Cost (\$): Operations

Facility/Administration

$\$ 2,421,000$

Operations

$\$ 19,791,000$

Procurement, materials, utilities, maintenance

$\$ 5,850,000$

Total operations

$\$ 28,062,000$

Schedule start/end

October 2010 through December 2019

Number of workers each year of operation (new/existing)

Operations

Maintenance

Support

Number of radiation workers

\section{2}

1

0.5

Average annual work radiation dose (rem/yr)

3 included in above

$0.1 \mathrm{rem}$ 
Table 5. (Continued) Project Data Sheet for Radioactive Liquid Waste Tanks

\section{Operational Information (Continued)}

Heavy Equipment

Air Emissions

Radioactive off-gas

Effluents

Sanitary Wastewater

Process water

Decontamination solution

Solid Wastes

Sanitary/Industrial Trash (@0.1 $\mathrm{ft}^{3} /$ person/day)

Radioactive wastes

Hazardous/toxic chemicals and wastes

Pits/Ponds used $\left(\mathrm{m}^{3}\right)$

Miscellaneous hazardous waste

Water usage

Process water

Domestic water

Energy Requirements

Electrical
None

Negligible

None

None

None

\section{$3.1 \mathrm{~m}^{3} /$ year} $1 \mathrm{~m}^{3} /$ year

None

$>1 \mathrm{~m}^{3} /$ year

None

None

500

\section{Decontamination \& Decommissioning (D\&D) Information}

\section{Cost (\$): D\&D}

Decommission

Decontamination

$\$ 200,000$

500,000

Demolition

$3,000,000$

Total D\&D

Schedule start/end: D\&D

$\$ 3,700,000$

January, 2013 through December, 2014

Number of workers each year of D\&D (new/existing)

20 
Table 5. (Continued) Project Data Sheet for Radioactive Liquid Waste Tanks

Decontamination \& Decommissioning (D\&D) Information (Continued).

Number of radiation workers (D\&D)

Average annual worker radiation dose (rem/yr)

\section{Heavy equipment}

Equipment used

Trips

Trucks

Hours of operation (all heavy equipment)

Acres disturbed and duration of disturbance

New

Previous

Revegetated

Air emissions

Non-radioactive Fuel combustion gases $\left(\mathrm{CO}_{2}, \mathrm{H}_{2} \mathrm{O}, \mathrm{O}_{2}\right.$,

$\mathrm{N}_{2}$ )

Non-radioactive Fuel combustion contaminants ( $\mathrm{CO}$, particulates, $\mathrm{NO}_{x}, \mathrm{SO}_{2}$, hydrocarbons)

Radioactive HEPA filtered off-gas

\section{Effluents}

Radioactive spent decontamination solution

Non-radioactive sanitary wastewater

Non-radioactive lube oil

\section{Solid wastes}

Radioactive

Non-radioactive (industrial)

Hazardous
20 included in the above

$0.5 \mathrm{rem}$

Mobile Cranes, Trucks, Dozers, Loaders

1 per day

$$
20,000 \text { hours (total) }
$$

none

3.4 acres

none

12,000 tons (total)

40 tons

negligible

70,000 liters

110,000 liters

negligible

$$
\begin{array}{r}
4,000 \mathrm{~m}^{3} \\
3,500 \mathrm{~m}^{3} \\
50 \mathrm{~m}^{3}
\end{array}
$$


Table 5. (Continued) Project Data Sheet for Radioactive Liquid Waste Tanks

Decontamination \& Decommissioning (D\&D) Information (Continued).

Hazardous/toxic chemicals and wastes (type)

Storage/inventory

Pits/ponds created $\left(\mathrm{m}^{2}\right)$

Radioactive (mixed waste)

Water usage

Process water

Domestic Water

Source of water

\section{Energy requirements}

Electrical (MWh/yr)

Fossil fuel (liters)

Permits needed (e.g. for facility closures, physical characteristics and quantities of radioactive and Hazardous materials remaining after closure) none

none

$10 \mathrm{~m}^{3}$ total

150,000 liters

none

ICPP site wells

$10 \mathrm{MWh} / \mathrm{yr}$.

90,000 liters

Work will be done under closure provisions of existing permits. 


\section{REFERENCES}

DOE-ID, Regulatory Analysis and Proposed Path Forward for the Idaho National Engineering Laboratory High-Level Waste Program, DOE/ID-10544, October 1996.

DOE-INEEL-STP, Site Treatment Plan, February 23, 1998

FR Vol. 62, Number 75, "Revised Technical Standards for Hazardous Waste Combustor Facilities", Federal Register, EPA, May 2, 1997.

Hoffman, T. L., Corrosion Monitoring of Storage Bins for Radioactive Calcines, ICP-1071, October 1975 ICPP Plant Safety Document (PSD), Section 8.3.

ICPP Plant Safety Review Document, Section 4.1, Utilities, ENI-113-4.1, Rev 1, September 1980

ICPP Plant Safety Document, Laboratory Facilities, Section 9.1C, WIN-107-9.1C, February 1994

ICPP Plant Safety Document, Final SAR for the Fifth Calcined Solids Storage Facility, ENICO-1068, Rev 1, February 1984

ICPP Plant Safety Document 8.6A, Liquid Effluent Treatment and Disposal Facility Final Safety Analysis Report, , WIN-107-8.6A, December 1992

ICPP Safety Document Addendum to Section 8.3C, Fourth CSSF Status, May 1994

ICPP Safety Assessment, PSD Section 8.3A Safety Assessment B for the First Calcined Solids Storage Facility Vault Isolation, WIN-107-8.3A SA-B Rev 0, Mar 1996a

ICPP Plant Safety Document 4.2, Aqueous Liquid Waste Management, WIN-107-4.2 Rev 9, March $1996 \mathrm{~b}$

ICPP, Plant Safety Document, Management of Radioactive Airborne Effluent, Section 8.6, WIN-107-8.6, February $1996 \mathrm{c}$

ICPP, Idaho Chemical Processing Plant Safety Analysis Report, Part II, Facility Specific Safety Analysis, Section 5.1, New Waste Calcining Facility, INEL-94/022, March 1998

Mozes, R. F., Project Design Criteria for the ICPP Seventh Calcined Solids Storage Facility, WIN-157, June 1985.

Murphy, James A., Pincock, Layne F., Christiansen, I. Niel, ICPP Radioactive Liquid and Calcine Waste Technologies Evaluation Final Report and Recommendation, INEL-94/0119, April 1995. Appendix A: Technology Descriptions

Palmer et. al., ICPP Tank Farm Systems Analysis, WINCO-1192, January 1994 
Palmer et. al., ICPP Tank Farm Planning Through 2012, INEEL/EXT-98-00339, April 1998

Rawlins, John K., Feasibility Study Report for NWCF MACT Compliance Facility, INEEL/INT-97-00992, November 1997

Schindler, R. E., Final Safety Analysis Report for the Fourth Calcined Solids Storage Facility, INICO11031, February 1980

Spaulding et. al., ICPP Tank Farm Closure Study, INEEL/EXT-97-01204, February 1998,

(USDOE 1997a). Final Waste Management Programmatic Environmental Impact Statement For Managing Treatment, Storage, and Disposal of Radioactive and Hazardous Waste, USDOE Office of Environmental Management, Summary, Page 1, DOE/EIS-0200-F, May, 1997.

USDOE 1997b Final Waste Management Programmatic Environmental Impact Statement For Managing Treatment, Storage, and Disposal of Radioactive and Hazardous Waste, USDOE Office of Environmental Management, Summary, Page 18, DOE/EIS-0200-F, May, 1997.

USDOE, Final Waste Management Programmatic Environmental Impact Statement For Managing Treatment, Storage, and Disposal of Radioactive and Hazardous Waste, USDOE Office of Environmental Management, Volume IV, Page E-7, DOE/EIS-0200-F, May, 1997.

Wichmann, Brooks, and Heiser, Regulatory Analysis and Proposed Path Forward for the Idaho National Engineering Laboratory High-Level Waste Program, DOE/ID-10544, October 1996. 


\section{M98054113}

|||||||||||||||||||||||||||||||||||||||||||||||||||||

Report Number (14) INEEL/EXT-98-00101

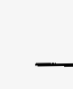

